\title{
ВИКОРИСТАННЯ ХМАРНИХ СЕРВІСІВ GОOGLЕ НА УРОКАХ МАТЕМАТИКИ
}

\author{
Нелін С. П. \\ кандидат педагогічних наук, професор, професор кафедри математики, \\ Харківський національний педагогічний університет імені Г. С. Сковороди, \\ м. Харків, Україна \\ Проскурня О. I.
}

кандидат педагогічних наук, доцент кафедри математики, Харківський національний педагогічний університет імені Г. С. Сковороди, м. Харків, Україна

\section{Цись Я. В.}

здобувач другого (магістерського) рівня вищої освіти, Харківський національний педагогічний університет імені Г. С. Сковороди, м. Харків, Україна

Авторами визначено перспективи упровадження в освітній процес закладу загальної середньої освіти у вивченні математики хмарних сервісів Google. Визначено позитивний вплив на уроках математики від залучення хмарних сервісів Google - Google-форми, яка сприяє інтенсифікації освітнього процесу.

Ключові слова: освітній прочес, організачія, урок математики, сервісів Google, інтенсифікація.

The authors identify the prospects for the introduction into the educational process of general secondary education in the study of mathematics in Google's cloud services. The positive influence on mathematics lessons from the involvement of Google cloud services - Google-form, which contributes to the intensification of the educational process.

Key words: educational process, organization, math lesson, Google services, intensification.

Останнім часом відбулася кардинальна зміна ролі та місця персональних комп'ютерів та інформаційних технологій у житті суспільства, без яких неможливо уявити сучасну людину. Досить часто використовуються інформаційні технології в освітньому процесі, що підвищує ефективність навчання.

Проникнення сучасних інформаційних технологій в освітню галузь дозволяє педагогам якісно змінити зміст, методи та організаційні фор- 
ми навчання. Метою застосування цих технологій в освіті є посилення інтелектуальних можливостей учнів в інформаційному суспільстві, а також інтенсифікація процесу навчання та підвищення якості навчання на всіх щаблях освітньої системи.

Використання комп'ютерної техніки робить урок нетрадиційним, яскравим, динамічним, інформаційно насиченим. Учні на таких уроках працюють активно і захоплено, в них розвивається допитливість, активізується пізнавальний інтерес.

Включення інформаційно-комунікаційних технологій до освітнього процесу перспективне, оскільки дозволяє педагогу:

- комплексно вирішувати освітні, виховні та розвивальні завдання;

- ставити кожному учневі конкретні завдання відповідно до його здібностей, рівня мотивації та підготовки;

- застосовувати різні типи електронних засобів навчального призначення, що активізують навчальну діяльність дітей;

• частково звільнитися від виконання інформаційної, тренувальної та контролюючої функцій;

- формувати в учнів навички самостійного оволодіння знаннями;

- стимулювати в учнів позитивну мотивацію до навчання шляхом інтегрування всіх форм наочності;

- організовувати навчальну діяльність учнів 3 негайним зворотним зв'язком та розвиненою системою допомоги.

Проведений аналіз наукової літератури $[1 ; 2 ; 3]$ та власний досвід надає підстави виокремити дієві форми та методи навчання математики, які сприяють урізноманітненню освітнього процесу різними прийомами організації навчальної діяльності.

Слід зазначити, що нещодавно на ринку інтернет-послуг з'явилися хмарні сервіси Google.

Саме поняття «хмарний сервіс» передбачає інтернет-сервіс, що дозволяє користувачеві зберігати файли не на своєму комп'ютері, а в Інтернеті. Можна навіть не встановлювати деякі програми, а працювати з їхніми онлайн-аналогами у браузері.

У пакеті Micorsoft Office можуть бути документи Google Docs.

До переваг хмарних сервісів можна віднести:

- доступ до документів з браузера практично з будь-якого пристрою - планшета, комп'ютера, смартфона, ноутбука;

- можливість створення, перегляду та редагування документів; 
- можливість імпорту звичайних документів та їх конвертації в інтернет-формат;

- спільний доступ до документів.

Ці можливості зручно використовувати для особливої організації навчального процесу, зокрема, для групової роботи.

Як позитивне, слід зазначити, що вчителі математики за допомогою хмарного сервісу Google організують роботу учнів наступним чином.

На уроках узагальнення та повторення вивченого класу розбивається на групи. Кожній групі видається набір завдань, у процесі виконання яких учні кожної групи виявляють тип свого завдання та оформлюють свій слайд презентації, що зберігається на google-диску. На цьому слайді вони дають назву своєму типу завдань, пропонують алгоритм розв'язання. Для економії часу вчитель може запропонувати учням різні формули, графіки, креслення, зібрані на одному слайді цієї презентації.

Представники кожної групи виконують завдання за окремими комп'ютерами паралельно. Отримана в результаті роботи презентація демонструється вчителем за допомогою проєктора, кожна група коментує свій слайд. Подібна організація освітнього процесу робить заняття динамічним та яскравим. Підсумкову презентацію учні можуть переглянути вдома та використовувати її для підготовки до контрольної роботи чи екзамену.

Хмарні сервіси Google, окрім звичних, пропонують новий тип документа - форму, яку зручно використовувати для анкетування учнів із метою діагностики рівня засвоєння ними знань. Форму ефективно застосовувати на етапі актуалізація знань, а також для контролю знань та у виховній роботі. Форма надає можливість створення тестів 3 різними типами відповідей (вибір зі списку, шкала, текст). вчитель може сам здійснювати обробку результатів за допомогою таблиці Excel або скористатися автоматичним зведенням відповідей у вигляді діаграм і графіків. Такий спосіб аналізу результатів дозволяє обговорити їх з учнями негайно, виявити прогалини у знаннях, виправити помилки, оцінити знання учнів.

Серед позитивних ефектів використання інформаційних технологій у процесі навчання - інтенсифікація освітнього процесу, розвиток інформаційно-комунікаційної компетентності учнів, діалог із учнями зрозумілою їм мовою. 


\section{Список використаних джерел:}

1. Жерновникова О.А. Психологічний аспект реалізації дистанційних освітніх технологій у навчальний процес майбутніх учителів математики. Наукові записки Бердянського державного педагогічного університету. Серія: Педагогічні науки : зб. наук. праць. Бердянськ : БДПУ, 2017. Вип. 2. C. 219-225.

2. Жерновникова О. А. Формування цифрової компетентності учителів математики в системі дистанційної освіти Moodle. Проблеми та шляхи реалізації компетентнісного підходу в сучасній освіті : матер. міжнар. наук.-метод. конф. (Харків, 11-12 квітня 2019 р.). Харків, 2019. C. $123-126$.

3. Штонда О. Г. Особливості застосування вебінарів у процесі дистанційного навчання. Інноваційні педагогічні технології в цифровій школі : матер. II наук.-практ. конф. молодих учених (14-15 травня 2020 р.). Харків : ХНПУ імені Г.С. Сковороди, 2020. С. 107-110. 